Андрій Зельницький, кандидат педагогічних наук, професор ORCID ID 0000-0002-3910-7329

Олег Заболотний, кандидат військових наук, доцент

ORCID ID 0000-0002-5950-5068

Олександр Васильєв,

ORCID ID 0000-0002-9492-5594

Надія Шабатіна

ORCID ID 0000-0002-5066-9517

Національний університет оборони України імені Івана Черняховського

DOI: 10.33099/2617-1775/2021-01/125-141

\title{
ІНФОРМАЦІЙНО-КОМУНІКАЦІЙНА КОМПЕТЕНТНІСТЬ ВИПУСКНИКА ВІЙСЬКОВОГО ВИШУ: ЗМІСТ, СТРУКТУРА, ВИМІРЮВАННЯ, ОЦНЮВАННЯ
}

У статті аналізуються наукові підходи щзодо визначення загального поняття "інформаційно-комунікативна компетентність" (далі - IКК) та ї̈ основних компонентів. Розглядаються структура $i$ зміст IKK та процедури ї̈ адаптації до особливостей організачії освітнього процесу у вищих військових навчальних закладах $і$ військових навчальних підрозділах закладів вищої освіти (далі - ВВНЗ). Досліджуються актуальні проблеми щуодо впровадження в педагогічну практику військових вишів розробленого інструментарію $з$ вимірювання та оцінювання рівня сформованості інформачійнокомунікативної компетентності у курсантів-випускників ВВНЗ як елементу зворотного зв'язку в системі управління якістю вищої військової освіти. Дослідження гармонізовано з відповідними положеннями Національної рамки кваліфікащій, Європейської кредитнотрансферної системи, Статутів Збройних Сил Украӥни, стандартів освіти та професійних стандартів підготовки військових фахівців, іншими нормативно-правовими актами.

Ключові слова: якість освіти; компетентність; випускник військового виту; інформаційно-комунікаційна компетентність; професійно важливі якості; показники вимірювання; критерії оцінювання; зворотний зв'язок.

Постановка проблеми. Забезпечення якості освіти та підготовки офіцерських кадрів до служби у військах (силах) постає як одна 3 пріоритетних проблем військової науки. П̈ї вирішення $\epsilon$ підгрунтям для подальшого реформування Збройних Сил України (далі - 3С України) та приведення військової освіти в Україні у відповідність до європейських та євроатлантичних освітніх стандартів. Важлива роль у цьому відводиться формуванню у майбутніх офіцерів певних компетентностей, де чільне місце посідає інформаційно-комунікаційна складова. Її пріоритетність обумовлена тенденціями світової глобалізації, підвищенням ролі інформатизації i комунікації в житті людини, суспільства, держави та їі структур. Як наслідок виникає потреба у підготовці фахівців за абсолютною більшістю спеціальностей в усіх галузях знань, у тому числі - в підготовці військових фахівців, спроможних орієнтуватися в інформаційних потоках, здатних 
знаходити, сприймати, аналізувати, зберігати та використовувати отриману інформацію у професійній діяльності. У зв’язку з цим постає проблема щодо розроблення змісту й структури інформаційно-комунікаційної компетентності (далі - IКК) та наукових підходів до визначення рівня іiі сформованості щодо сфери військової освіти. Саме на розв'язання зазначеної проблеми спрямовано дану статтю.

\section{Аналіз останніх досліджень і публікацій.}

Загальним проблемам якості вищої освіти та управління нею присвячені наукові праці вчених В. П. Андрущенка [1], В.Г. Кременя [17], Б. С. Гершунского [7], С. У. Гончаренко [8] та ін. Щодо проблеми формування інформаційно-комунікативної компетентності студентів та викладачів цивільних вишів - наукові праці М. А. Антонченка [2], Л. В. Астахової [3], М. Баловсяка [4], О. Б. Зайцевої [10], Ю. С. Рамського [23], Т. Торбіної [26], С. В. Тришиної, А. В.Хуторського [27], В. Д. Шадрікова [29] та ін. Проблемам формування професійних компетентностей та інформаційно-комунікаційної компетентності військових фахівців присвятили свої наукові праці А. О. Вітченко, В. І. Осьодло, С. М. Салкуцан [6, 23], О. П. Свсюков [9], С. Д. Максименко [18], С. А. Мул [20], В. В. Ягупов, В. І. Свистун [30], А. М. Зельницький, О. А. Заболотний [13 - 16, 20, 21] та інші.

Аналіз досліджень і публікацій згаданих авторів значною мірою сприяв виробленню змісту та структури IКК, розробленню інструментарію 3 вимірювання та оцінювання рівня сформованості інформаційно-комунікативної компетентності у курсантів-випускників ВВН3 як елементу зворотного зв’язку в системі управління якістю професійної підготовки майбутніх офіцерів у ВВН3 та впровадженню в педагогічну практику військових вишів

Мета статті - обгрунтувати концептуальні підходи до визначення змісту і структури інформаційно-комунікаційної компетентності випускника військового вишу, розробити інструментарій щодо вимірювання та оцінювання рівня сформованості IКК та здійснити апробацію розробленого інструментарію (у режимі самооцінювання) із залученням курсантів випускного курсу ВВН3, ВНП ЗВО.

Методи дослідження. Дослідження проведене із застосуванням таких теоретичних методів: системний аналіз і синтез, індукція та дедукція, порівняння, класифікація, узагальнення й систематизація; ідеалізація та абстрагування.

Виклад основного матеріалу. Одним 3 основних показників якості та ефективності освітнього процесу вишів є професійна компетентність здобувача освіти, яку можна розглядати як інтегральну характеристику ділових та особистісних якостей фахівця, що відображає його готовність ефективно діяти, а також взаємодіяти при вирішенні професійних завдань різного рівня складності. Особливістю професійної компетентності військового фахівця є те, що окрім зазначеного вище він має бути здатним приймати відповідальні рішення при виконанні функціональних обов'язків на посаді за призначенням у військах (силах) та готовим ефективно діяти в змінюваних умовах мирного i 
воєнного часу на основі творчого застосування набутих знань, сформованих умінь, навиків і досвіду [16, с. 65-70].

Варто звернути увагу на те, що компетентність офіцера визначається не стільки рівнем засвоєння академічних знань, скільки здатністю і готовністю творчо їх застосовувати в змінюваних умовах службової діяльності. При цьому, поняття “здатність” свідчить про властивість індивіда здійснювати, виконувати, робити що-небудь, поводити себе певним чином [5, с. 360], а "готовність (готовий)" - це стан індивіда, який набув досвіду, досяг високої майстерності, підготувався до чого-небудь [5, с. 194].

3 поміж низки компетентностей, належне місце посідає інформаційнокомунікаційна. У сучасному суспільстві процес інформатизації носить дуже широкий характер. Важко знайти галузь людської діяльності, що не пов'язана 3 інформаційними перетвореннями. Суть і джерело таких перетворень криється в зміні ролі інформації в житті людини, суспільства і його структур, в зростаючій ролі інформаційних процесів. Це потребує сформованості в особистості відповідної інформаційно-комунікаційної компетентності на рівні, що дозволяє ii носію впевнено почуватися в сучасному інформаційному середовищі, використовувати здобуту з різних джерел інформацію у професійній діяльності.

У науковій літературі поняття інформаційно-комунікаційна компетентність (далі - IKК) трактується науковцями неоднозначно. Окремі дослідники ІКК розглядають як складову професійної компетентності. Інші вважають, що це поняття пов'язане з поняттям “культура”, і розглядають його у взаємозв’язку 3 поняттями “інформаційна грамотність”, “інформаційна культура", що характеризують рівень розвитку особистості.” Так, Б. Гершунський основою професійної компетентності називає грамотність i освіченість, $з$ іншого боку, на думку автора, професійна компетентність $\epsilon$ основою становлення культури і менталітету, тобто в структурному ланцюжку результативності освіти доцільно виділити такі компоненти: “грамотність", “освіченість”, “компетентність”, “культура”, “менталітет [7, с. 369].

Часто ІКК розглядається у межах інформаційно-комунікаційної технології як готовність і здатність особистості самостійно і відповідально використовувати ці технології у своїй професійній діяльності тощо.

Різноманітність наведених та інших підходів до визначення поняття “інформаційно-комунікаційна компетентність” та необхідність адаптації ІКК до особливостей підготовки майбутніх офіцерів у ВВНЗ потребує проведення дефінітивного аналізу основних компонентів зазначеного поняття, зокрема: “інформація”, “комунікація”, “інформаційна компетентність”, “комунікативна компетентність”, “професійна компетентність”. Здійснення подібного аналізу слугуватиме підгрунтям для аргументованого наповнення змістом основного поняття - “інформаційно-комунікаційна компетентність випускника військового вишу" та сприятиме розгляду відповідних наукових підходів, пов'язаних із структуризацією, оцінюванням та вимірюванням IКК, що $є$ предметами даного дослідження. 
Наведемо визначення основних понять стосовно до інформаційнокомунікаційної компетентності та їх змісту, представлених у різних психологопедагогічних та інших літературних джерелах, отже:

інформація - (франц. informo - створюю уявлення про щось, зображую) відомості про які-небудь події, ситуації, чиюсь діяльність тощо [25, С. 314];

комунікація - (лат. communicatio - зв'язок, повідомлення) - повідомлення інформації від однієї людини до іншої, або кількох інших; поширення інформації за допомогою технічних засобів [25, С. 370];

компетентність - (англ. competence - здатність, Міжнародний стандарт $I S O: 9000)$ - доведена здатність застосовувати знання i навички задля досягнення визначених результатів [19];

компетентність - динамічна комбінація знань, умінь, навичок, способів мислення, поглядів, цінностей, інших особистих якостей, що визначає здатність особи успішно соціалізуватися, провадити професійну та/або подальшу навчальну діяльність [11];

компетентність - динамічна комбінація знань, вмінь і практичних навичок, способів мислення, професійних, світоглядних i громадянських якостей, морально-етичних цінностей, яка визначає здатність особи успішно здійснювати професійну та подальшу навчальну діяльність і $є$ результатом навчання на певному рівні вищої освіти [12];

професія [лат. professio; від profiteer -“об'являю своєю справою”] - рід трудової діяльності, що вимагає спеціальних теоретичних знань та практичних навичок і є джерелом існування [25, с.569];

Інформаційна компетентність - складне індивідуально-психологічне утворення на основі інтеграції теоретичних знань, практичних умінь в області інноваційних технологій і певного набору особистісних якостей [10];

інформаційна компетентність - якість особистості, що являє собою сукупність знань, умінь і ціннісного ставлення до ефективного здійснення різних видів інформаційної діяльності та використання нових інформаційних технологій для вирішення соціально значущих завдань, що виникають в реальних ситуаціях повсякденного життя людини в суспільстві [2; 4];

інформаційна компетентність - це здатність людини виконувати пізнавальні i комунікаційні операції інформаційної діяльності 3 метою реалізації іiі інформаційних потреб як відправника i одержувача інформації [3];

інформаційна компетентність - вміння самостійно шукати, аналізувати і відбирати необхідну інформацію, організовувати, перетворювати, зберігати i передавати іiї за допомогою реальних об'єктів та інформаційних технологій [27].

Варто зазначити, що структура інформаційної компетентності включає три основні компоненти: гносеологічний, праксиологічний, аксіологічний.

Гносеологічний компонент - характеризує знаннєву складову інформаційної компетентності і включає в себе всі елементи знання, необхідні і достатні для орієнтування в сучасному інформаційному просторі.

Праксиологічний компонент включає в себе вміння i навички інформаційної діяльності особистості, що дозволяють застосовувати сучасні 
технології реалізації інформаційних процесів у практиці навчальної, науковонавчальної та професійної діяльності.

Аксіологічний компонент - детермінує мотиваційно-ціннісну складову інформаційної компетенції: це цінності i ціннісні орієнтації, мотиви інформаційної діяльності, критичне ставлення до сприйняття і адекватна оцінка істинності інформації, готовність до самоосвіти, усвідомлення її необхідності.

У ході навчання інформаційна компетентність виступає як мінімум в трьох ролях: як одна 3 ключових компетентностей особистості; як базис, необхідний для формування загальнокультурних і професійних компетентностей; як один 3 інструментів виконання професійних завдань та реалізації інших компетенцій.

Під комунікативною компетентністю слід розуміти здатність людини встановлювати і підтримувати необхідні контакти 3 іншими людьми, певна сукупність знань, умінь і навичок, що забезпечують ефективне спілкування. Комунікативна компетентність передбачає уміння змінювати глибину і коло спілкування, розуміти і бути зрозумілим для партнера по спілкуванню.

Комунікативна компетентність формується, переважно, в умовах безпосередньої взаємодії людей i $\epsilon$ результатом накопичення досвіду спілкування між ними. Разом з тим, зазначений досвід накопичується не тільки у процесі безпосередньої взаємодії в ході спілкування людей. Він набувається також у ході опосередкованої взаємодії, в тому числі - 3 таких джерел як література, театр, кіно, Інтернет тощо. Людина з цього культурного середовища запозичує інформацію про характер комунікативних ситуацій та засоби їх аналізу у вигляді словесних i візуальних форм, що сприяє розвитку вмінь адекватної самооцінки, орієнтації людини в самій собі - власному психологічному потенціалі та потенціалі партнера.

На основі різноманітності застосовуваних у спілкуванні знакових систем, що притаманні комунікативній компетентності, вирізняють вербальну i невербальну комунікації.

Вербальна комунікація використовує в якості знакової системи людську вимову, природну звукову мову, тобто систему фонетичних звуків, що базується на лексичному і синтаксичному принципах

Невербальна комунікація включає жести, міміку, пантоміміку, паузи і темп мовлення, візуальний контакт (частота обміну поглядами, тривалість, зміна статики і динаміки погляду або його уникання), а також організацію простору і часу комунікативного процесу тощо.

У структурі комунікативної компетентності доцільно виокремити такі складові:

орієнтованість у різноманітних ситуаціях спілкування, яка заснована на знаннях і життєвому досвіді індивіда;

спроможність ефективно взаємодіяти з оточенням завдяки розумінню себе й інших при постійній видозміні психічних станів, міжособистісних відносин і умов соціального середовища;

адекватна орієнтація людини в самій собі-власному психологічному потенціалі, потенціалі партнера, у ситуації;

готовність і уміння будувати контакт з людьми; 
внутрішні засоби регуляції комунікативних дій ;

знання, уміння і навички конструктивного спілкування;

внутрішні ресурси, необхідні для побудови ефективної комунікативної дії у визначеному колі ситуацій міжособистісної взаємодії.

Отже, комунікативна компетентність постає як структурний феномен, що містить певні складові: цінності, мотиви, установки , соціально-психологічні стереотипи, знання, уміння, навички конструктивного спілкування тощо. У контексті проблеми ефективності спілкування доцільно згадати й про таке явище в людській взаємодії, як роль. Роль $є$ фіксацією визначеного положення, що займає той або інший індивід у системі міжособистісних відносин. У психології виокремлюють такі ролі: формальні; внутрішньогрупові; міжособистісні; індивідуальні ролі.

Формальна роль - це поведінка , що будується відповідно до засвоєних очікувань з боку оточення, пов'язаних з виконанням тієї чи іншої соціальної функції (інституціолізовані, пов'язані 3 офіційними вимогами організації: підлеглий , керівник і т.д.);

Внутрішньогрупова роль - це поведінка, що вимагає урахування очікувань, запропонованих учасниками групи на основі сформованих взаємовідносин.

Міжособистісні ролі - це поведінка, яка передбачає урахування очікувань, запропонованих іншою людиною на основі сформованих відносин.

Однією із складових комунікативної компетентності $\epsilon$ уміння усвідомлювати і долати комунікативні бар'єри. Такі бар'єри можуть виникати, наприклад, при відсутності розуміння ситуації спілкування, що викликається розходженнями між партнерами (соціальними, політичними, релігійними, фаховими, які породжують різну інтерпретацію тих самих понять, що обумовлюють різноманітне світовідчуття, світогляд, світосприймання).

Бар'єри у комунікації можуть носити також психологічний характер, відображаючи індивідуальні психологічні особливості тих, хто спілкується, їхні сформовані відношення: від дружби до ворожості по відношенню один до одного.

Таким чином, проведення дефінітивного аналізу основних компонентів поняття ІКК, зокрема: “інформація", “комунікація”, “компетентність", “професійна компетентність", “інформаційна компетентність", “комунікативна компетентність" є підгрунтям для змістового наповнення основного поняття “інформаційно-комунікаційна компетентність випускника військового вишу”.

Отже, інформаційно-комунікаційна компетентність випускника військового вишу це інтегральний показник сформованості в нього на визначеному рівні відповідних професійно важливих якостей (далі - ПВЯ) щодо готовності реалізовувати в практичній діяльності процедури пошуку, аналізу, обробки, передачі, обміну та зберігання інформації.

Щодо розкриття сутності поняття ПВЯ то найбільш точно та ємно, на наш погляд, $\epsilon$ визначення, представлене В.Д. Шадріковим. Під професійно важливими якостями він розуміє “індивідуальні якості суб'єкта діяльності, що впливають на ефективність професійної діяльності та успішність їі засвоєння " 
$[29$, с. 66]. Це визначення є загальним та слушним для фахівця будь-якої професії.

Отже, проведення дефінітивного аналізу загального поняття “інформаційно-комунікаційна компетентність” та виявлення взаємозв'язків і взаємозалежностей між складовими цього поняття сприяло створенню відповідної структури як цілісної системи, змістовому наповненню кожного з іiі компонентів i розробленню адекватних підходів до їх вимірювання та оцінювання. Зазначені процедури було здійснено найбільш компетентними фахівцями ВВНЗ у галузі воєнної педагогіки із застосуванням методу експертних оцінок, що знайшло своє відображення у розробленому опитувальнику із самооцінювання курсантами-старшокурсниками ВВНЗ рівня сформованості в них інформаційно-комунікаційної компетентності (Таблиия 1).

Представлені у таблиці ПВЯ, що $\epsilon$ показниками інформаційнокомунікаційної компетентності, розкривають загальні вимоги до сформованості ІКК майбутнього офіцера, а саме - його здатність та готовність застосовувати в практичній діяльності різноманітні способи та особливості пошуку, аналізу, обробки, передачі, зберігання інформації та обміну нею.

Таблиия 1

Опитувальник із самооцінювання курсантами-старшокурсниками ВВНЗ рівня сформованості в них інформаційно-комунікаційної компетентності

\begin{tabular}{|c|c|c|c|}
\hline \multirow{2}{*}{$\begin{array}{l}\text { № } \\
3 / n\end{array}$} & \multirow{2}{*}{$\begin{array}{l}\text { Перелік професійно-важливих якостей } \\
\begin{array}{l}\text { (ПВЯ) } \\
\text { комунікаційної }\end{array} \\
\begin{array}{l}\text { (здатність): } \\
\text { інфохормаційно- }\end{array} \\
\text { компетентності }\end{array}$} & \multicolumn{2}{|c|}{ Результати оцінювання } \\
\hline & & (бали) & $(\%)$ \\
\hline 1 & 2 & 3 & 4 \\
\hline 1. & $\begin{array}{l}\text { Вільно спілкуватися державною мовою } \\
\text { відповідно до норм сучасної літературної } \\
\text { мови }\end{array}$ & $\mathrm{H}+1+\mathrm{H}_{\mathrm{H}}$ & $90 \%$ \\
\hline 2. & $\begin{array}{l}\text { Ясно, чітко, системно, аргументовано та } \\
\text { переконливо висловлювати власну думку }\end{array}$ & 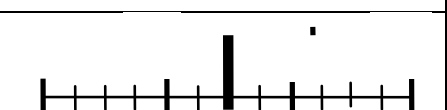 & $70 \%$ \\
\hline 3. & $\begin{array}{l}\text { Терпимо сприймати іншу точку зору, що не } \\
\text { збігається з особистою (толерантність) }\end{array}$ & $1+1+1+1+1+1$ & \\
\hline 4. & Легко вступати в контакт з іншими особами & $\mathrm{H}+1+1+1+\mathrm{H}$ & \\
\hline 5. & Уникати конфліктів, розв'язувати їх & $\mathrm{H}+\mathrm{H}+1 \mathrm{H}+\mathrm{H}$ & \\
\hline 6. & Користуватися ПК в інтересах служби & $1+1+1+1+1+1$ & \\
\hline 7. & Володіти іноземною (англійською) мовою: & $\mathrm{H}+\mathrm{H}+1 \mathrm{H}+1 \mathrm{H}$ & \\
\hline & 7.1. говоріння & $1+1+1+1+H$ & \\
\hline
\end{tabular}




\begin{tabular}{|c|c|c|c|c|}
\hline & \multicolumn{2}{|l|}{ 7.2. читання } & $\mathrm{H}+\mathrm{H}+1+1+\mathrm{H}$ & \\
\hline & \multicolumn{2}{|l|}{ 7.3. аудіювання } & $\mathrm{H}+1+1+\mathrm{H}$ & \\
\hline & \multicolumn{2}{|l|}{ 7.4. письмо } & $\mathrm{H}+\mathrm{H}+\mathrm{H}+\mathrm{H}$ & \\
\hline 8. & \multicolumn{2}{|c|}{$\begin{array}{l}\text { Знаходити, сприймати, аналізувати, } \\
\text { систематизувати та передавати інформацію, } \\
\text { отриману } 3 \text { вітчизняних інформаційних } \\
\text { джерел, зокрема у військовій сфері }\end{array}$} & $\mathrm{H}+1+1+1+\mathrm{H}$ & \\
\hline 9. & \multicolumn{2}{|c|}{$\begin{array}{l}\text { Знаходити, сприймати, аналізувати, } \\
\text { систематизувати та передавати інформацію, } \\
\text { отриману } 3 \text { іноземних інформаційних } \\
\text { джерел, зокрема у військовій сфері (країни } \\
\text { НАТО) }\end{array}$} & $\mathrm{H}+\mathrm{H}+\mathrm{H}+\mathrm{H}$ & \\
\hline 10. & \multicolumn{2}{|c|}{$\begin{array}{l}\text { Ефективно спілкуватися в умовах дефіциту } \\
\text { часу, небезпеки, суперечливості обстановки }\end{array}$} & $H+1+1+1+H$ & \\
\hline 11. & \multicolumn{2}{|c|}{$\begin{array}{l}\text { Чітко звітувати, доповідати у військово- } \\
\text { професійному середовищі }\end{array}$} & $1+1+1+1+1+1$ & \\
\hline \multirow[t]{2}{*}{12.} & \multirow{2}{*}{$\begin{array}{lr}\text { Інтегральний } & \text { показник рівня } \\
\text { сформованості } & \text { інформаційно- } \\
\text { комунікаційної } & \text { компетентності } \\
\text { курсанта (середньоарифметичне за } \\
\text { всіма ПВЯ) }\end{array}$} & Бали & $\begin{array}{r}\text { Наприклад: } \\
\mathbf{3 , 8 6} \text { бали }\end{array}$ & \\
\hline & & $\%$ & $\begin{array}{c}\text { В абсолютних пока } \\
\mathbf{7 7 , 2 \%}\end{array}$ & зниках - \\
\hline
\end{tabular}

У таблиці також наведено шкалу, що дозволяє здійснювати вимірювання кожної з ПВЯ та оцінювання ІКК у цілому. Шкала є 4-и бальною - від бала "2" до бала “5”. Найвищий бал “5” свідчить про еталонний прояв показника, найнижчий бал - “2” свідчить про те, що показник зовсім не проявився. Решта відповідно. 3 метою більш точного вимірювання зазначену шкалу подрібнено із ціною поділки у 0,25 бали (див. Таблищю 1).

Процедура вимірювання кожної з ПВЯ є достатньо спрощеною. Для цього суб'єкту вимірювання потрібно поставити позначку (вертикальну риску) у тому місці оцінної шкали, що на його думку свідчить про рівень сформованості даного показника на даний час. Так, наприклад, прояв показника № 1 - “Вільно спілкуватися державною мовою..." оцінений вертикальною рискою у 4,5 бали, а показника № 2 - “Ясно, чітко, системно, аргументовано та переконливо висловлювати власну думку" оцінений вертикальною рискою у 3,5 бали (див. Таблицю 1).

При цьому слід наголосити, що оцінна шкала призначена для вимірювання прояву представлених у таблиці ПВЯ в абсолютних показниках - балах. Для проведення аналізу отриманих результатів опитування слід здійснити перехід від абсолютних до відносних показників. Сутність подібного переходу полягатиме у співвідношенні визначеного суб'єктом вимірювання абсолютного 
значення будь-якого показника (в балах) 3 еталонним показником - бал "5" відповідно до наведеної формули 1. При цьому, прояв показника, оцінений балом “2” прирівнюється до “0”.

$$
K_{i j}=\frac{P_{i j}}{P_{j}^{e m}}
$$

де: $K_{i j}$ - відносний показник прояву $j$-го критерію ( де $i-$ № № критеріїв, у даному випадку - в Таблиці 1 - від № 1 до № 11) за результатами опитування $j$-го курсанта;

$P_{i j}$ - абсолютний показник прояву $i$-го критерію, що проставлений в опитувальнику j-м курсантом - від балу “2” до балу “5”;

$$
P_{j}^{e m} \text { - еталонний показник прояву j-го критерію - (бал “5”). }
$$

Наприклад, якщо абсолютний показник № 1 (див. Таблицю 1) -“Вільно спілкуватися державною мовою...” оцінено на шкалі у 4,5 бали, то відносний показник $\mathrm{K}_{1}=4,5: 5=0,9$. А якщо, припустимо, абсолютний показник № 2 (див. Таблиц̧ю 1) - “Ясно, чітко, системно, аргументовано та переконливо висловлювати власну думку" оцінено на шкалі у 3,5 бали, то відносний показник $\mathrm{K}_{2}=3,5: 5=0,7$. Для переведення значень абсолютних показників у відносні (\%) достатньо перемножити їх значення на 100\%, наприклад: К1 = 0,9 х $100 \%=90 \%$.

А якщо будь-який 3 показників оцінено у 2,0 бали, то $\mathrm{K}_{i}=0: 5=0$. Аналогічно визначається прояв усіх інших показників.

Далі підраховується $K_{j i \kappa \kappa}$-інтегральний показник рівня сформованості в j-го слухача інформаційно-комунікаційної компетентності як середньоарифметичне значення $K_{i j}$ за кожним з $i$ - $x$ відносних показників, що оцінені $j$-м слухачем (курсантом) у навчальній групі за формулою 2.

$$
K_{j i \kappa \kappa}=\frac{\sum_{i=1}^{n} K_{i j}}{n}
$$

де: $K_{j i \kappa \kappa}-$ інтегральний показник рівня сформованості в $j$-го слухача зазначеної $I K K$;

$K_{i j}$ - відносний показник прояву $i$-го критерію за опитуванням $j$-го слухача (курсанта); 


$$
\sum_{i=1}^{n} K_{i j}
$$

- сума відносних показників прояву $i$ - $x$ критеріїв за опитуванням $j$ го слухача;

$n$ - кількість $i$ - $x$ критеріїв у межах ІКК.

Як приклад, інтегральний показник рівня сформованості інформаційнокомунікаційної компетентності $K j_{i \kappa \kappa}$, підрахований за формулою (2) для $j$-го слухача склав у абсолютних показниках 3,86 бали, що у відносних показниках відповідає 77,2 \% (див. Таблицю 1).

Оброблені результати реального самооцінювання рівня сформованості інформаційно-комунікаційної компетентності $j$-го здобувача представлені в таблиці (див. Таблицю 2). Наведені в ній цифрові показники є підгрунтям для проведення відповідного аналізу. Так, інтегральний показник рівня сформованості ІКК $-K_{\text {iкк }}$ в $j$-го здобувача склав за результатами вимірювання кожної із професійно важливих якостей у 4-х бальній шкалі - 3,93 бали, що відповідає 78,6 у \% (див. Таблищю 2).

Як оцінити такий рівень? Чи є він достатнім для ствердження про готовність здобувача освіти використовувати відповідні професійно важливі якості, що сформовані в межах даної компетентності, у практичній діяльності?

Для відповіді на ці запитання варто скористатися принципами, визначеними в ЄКТС - Свропейська кредитно-трансферна система (з англ. European Credit Transfer System-ECTS). Зазначена система створена для забезпечення єдиної міждержавної процедури виміру й порівняння між закладами освіти результатів навчання студентів, їхнього академічного визнання. Відповідно до шкали оцінювання за системою EKTS задовільний рівень сформованості будь-якої компетентності має перевищувати $60 \%$.

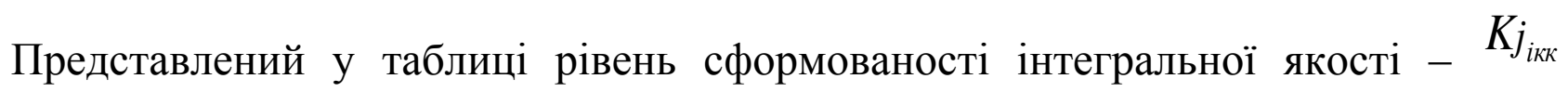
$=78,6 \%$ (див. Таблицю 2). Згідно із шкалою оцінювання системи EKTS такий кількісний показник відповідає оцінці “добре” (81-90\%). Інші оцінні показники, що представлені в системі EKTS, є такими: “відмінно” - 91 -100\%; “дуже добре" - 81- 90 \%; “добре”-71- 80 \%; “задовільно” - 61-70 \%.

Так, наприклад, рівень сформованості показника № 9 - “Знаходити, сприймати, аналізувати, систематизувати та передавати інформацію, отриману з іноземних інформаційних джерел, у тому числі - у військовій сфері (країни НАТО)" склав 3,25 бали або 65,0\%.

Найвищі цифрові значення за результатами самооцінювання здобули показники № 4 - “Легко вступати в контакт з іншими особами” - 4,5 бали або 90,0 \% та № 6 - “Користуватися ПК в інтересах служби” - 4,5 бали або 90,0\%. Найнижчі цифрові значення характеризують рівень сформованості показника № 7 "Володіти іноземною (англійською) мовою" зокрема: 7,3 “аудіювання" 55,0 \% та 7,1 “говоріння” - 60,0\% (див.Таблищю 2). Проведення подібного аналізу щодо результатів самооцінювання курсантами-старшокурсниками 
ВВНЗ рівня сформованості в них інформаційно-комунікаційної компетентності, а за аналогією - й інших компетентностей, сприятиме оптимізації процесу управління якістю підготовки майбутніх офіцерів для ЗС України.

Таблиия 2

\section{Результати самооцінювання курсантом-старшокурсником ВВНЗ рівня сформованості в нього інформаційно-комунікаційної компетентності}

\begin{tabular}{|c|c|c|c|c|}
\hline \multirow[t]{2}{*}{ № $3 / n$} & \multirow{2}{*}{\multicolumn{2}{|c|}{$\begin{array}{l}\text { Перелік професійно-важливих якостей (ПВЯ) } \\
\text { в межах інформаційно-комунікаційної } \\
\text { компетентності (здатність): }\end{array}$}} & \multicolumn{2}{|c|}{ Результати оцінювання } \\
\hline & & & (середній бал) & $(\%)$ \\
\hline 1. & \multicolumn{2}{|c|}{$\begin{array}{l}\text { Вільно спілкуватися державною мовою } \\
\text { відповідно до норм сучасної літературної мови, } \\
\text { мислити українською }\end{array}$} & 4,00 & 80,0 \\
\hline 2. & \multicolumn{2}{|c|}{$\begin{array}{l}\text { Ясно, чітко, системно, аргументовано } \\
\text { переконливо висловлювати власну думку }\end{array}$} & 3,75 & 75,0 \\
\hline 3. & \multicolumn{2}{|c|}{$\begin{array}{l}\text { Терпимо сприймати іншу точку зору, що не } \\
\text { збігається з особистою (толерантність) }\end{array}$} & 4,25 & 85,0 \\
\hline 4. & \multicolumn{2}{|c|}{ Легко вступати в контакт з іншими особами, } & 4,50 & 90,0 \\
\hline 5. & \multicolumn{2}{|c|}{ Уникати конфліктів, розв’язувати їх } & 4,25 & 85,0 \\
\hline 6. & \multicolumn{2}{|c|}{ Користуватися ПК в інтересах служби } & 4,50 & 90,0 \\
\hline \multirow[t]{5}{*}{7.} & \multicolumn{2}{|c|}{ Володіти іноземною (англійською) мовою: } & 3,19 & 63,8 \\
\hline & \multicolumn{2}{|l|}{ 7.1. говоріння } & 3,00 & 60,0 \\
\hline & \multicolumn{2}{|l|}{ 7.2. читання } & 3,50 & 70,0 \\
\hline & \multicolumn{2}{|l|}{ 7.3. аудіювання } & 2,75 & 55,0 \\
\hline & \multicolumn{2}{|l|}{ 7.4. письмо } & 3,50 & 70,0 \\
\hline 8. & \multicolumn{2}{|c|}{$\begin{array}{lll}\text { Знаходити, } & \text { сприймати, } & \text { аналізувати, } \\
\text { систематизувати та передавати } & \text { інформацію, } \\
\text { отриману з вітчизняних інформаційних джерел, у } \\
\text { тому числі - у військовій сфері }\end{array}$} & 3,75 & 75,0 \\
\hline 9. & \multicolumn{2}{|c|}{ 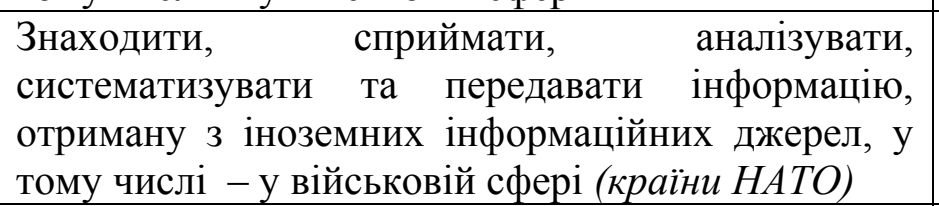 } & 3,25 & 65,0 \\
\hline 10. & \multicolumn{2}{|c|}{$\begin{array}{l}\text { Ефективно спілкуватися в умовах дефіциту часу, } \\
\text { небезпеки, суперечливості обстановки }\end{array}$} & 3,75 & 75,0 \\
\hline 11. & \multicolumn{2}{|c|}{$\begin{array}{l}\text { Чітко звітувати, доповідати } \\
\text { професійному середовищі }\end{array}$} & 4,00 & 80,0 \\
\hline \multirow[t]{2}{*}{12.} & \multirow[b]{2}{*}{$\begin{array}{l}\text { Інтегральний показник } \\
\text { рівня сформованості } \\
\text { інформаційно- } \\
\text { комунікаційної } \\
\text { компетентності здобувача } \\
\text { освіти }\end{array}$} & Бали & 3,93 (бали) & - \\
\hline & & $K j_{i \kappa \kappa}$ & - & $78,6(\%)$ \\
\hline
\end{tabular}

Висновки та перспективи подальших досліджень. Таким чином, у статті проаналізовано зміст загального поняття "інформаційно-комунікативна компетентність" (ІКК), яке адаптовано до особливостей організації освітнього процесу у вищих військових навчальних закладах i військових навчальних підрозділах закладів вищої освіти. 
Розроблено компетентнісну модель ІКК, структурними елементами якої $\epsilon$ органічно пов'язані між собою професійно важливі якості майбутніх офіцерів щодо їх здатності та готовності орієнтуватися в інформаційних потоках, знаходити, сприймати, аналізувати, зберігати та використовувати отриману інформацію у професійній діяльності.

Досліджено актуальні проблеми стосовно впровадження в педагогічну практику військових вишів розробленого інструментарію з вимірювання та оцінювання рівня сформованості інформаційно-комунікативної компетентності курсантів (слухачів) як елементу зворотного зв'язку в системі управління якістю вищої військової освіти.

Подальші дослідження у контексті зазначеної проблеми доцільно спрямувати на автоматизацію процесу зворотного зв'язку між суб'єктами освітнього процесу військових вишів.

\section{ЛІТЕРАТУРА}

1. Андрущенко В. П. Теоретико-методологічні засади модернізації вищої освіти в України на рубежі століть (за матеріалами доповіді, виголошеної на засіданні загальних зборів АПН України 23 листопада 2000 р.) // Вища освіта України. - 2001. - № 2. - С. 5-13.

2. Антонченко М. А. Інформаційна культура як складова загальнолюдської культури // Науковий часопис НПУ імені М.П. Драгоманова. Серія № 2. Комп’ютерно-орієнтовані системи навчання: Зб. Наукових праць. - К.: НПУ імені М.П. Драгоманова, 2004. - № 1(8). C.161-166.

3. Астахова Л. В. Понятие информационной компетенции специалиста: когнитивный подход // Вестник ЮУрГУ. Серия: Образование. Педагогические науки. - 2013. - № 4. C. $10-16$.

4. Баловсяк М. Інформаційна компетентність фахівця // Педагогіка і психологія професійної освіти. - 2004. - № 5. - С. 21-28.

5. Великий тлумачний словник сучасної української мови / Уклад. і голов. ред. В.Т. Бусел. - К.- Ірпінь: ВТФ “Перун”, 2001. - 1440 с.

6. Вітченко А.О., Осьодло В.І., Салкуцан С.М. Технології навчання у вищій військовій школі: теорія і практика: навч.-метод. посіб. / За заг. ред. професора В.М. Телелима. - К. : НУОУ імені Івана Черняховського, 2016. - 272 с.

7. Гершунский Б. С. Философия образования. - М.: «Флинта», 1998. - 492 с.

8. Гончаренко С. У. Український педагогічний словник. - К.: Либідь, 1997. - 376 с

9. Свсюков О.П. Психологічне прогнозування професійної надійності фахівців аварійно-рятувальних підрозділів МНС України: дис. ...кандидата пед. наук : 19.00.09/ Свсюков Олександр Петрович. - Харків, 2007. - С. 90.

10. Зайцева О. Б. Информационная компетентность учителя образовательной области «Технология» / О. Б.Зайцева // Педагогика. - № 4. - 2004. - С.17-23.

11. Про освіту: Закон України від 05.09.2017 р. №2145-VIII. // Відомості Верховної Ради. - 2017. - № 38-39. - Ст. 380.

12. Про вищу освіту: Закон України від 01.07.2014 р. № 1556-VII. (Дата оновлення: 28.09.2017.) URL: http://zakon4.rada.gov.ua/laws/show/1556-18/page2 (Дата звернення: 15.11.2017).

13. Зельницький А. М. Компетентнісна модель випускника ВВНЗ - складова системи підготовки військових фахівців / Зельницький А.М., Удовенко П.І., Серветник Р.М. // Вісник Національної академії оборони України. - 2009. - № 3 (11). - С. 21-26.

14. Зельницький А. М. Відгук з військ на випускника ВВНЗ, ВНП ВНЗ у системі управління якістю підготовки військових фахівців / А. М. Зельницький // Вісник Національного університету оборони України. - 2011. - Вип. 1. - С. 14-25. 
15. Зельницький А. М. Проблема якості підготовки офіцерів тактичної ланки управління в контексті проведення АТО / А.М. Зельницький, Ю.І. Приходько, О.О. Мітягін // Збірник наук. праць «Військова освіта» Національного університету оборони України. № 1(31). - 2015. - С. 93-102.

16. Зельницький А. М. Якість військової освіти: iï забезпечення та гарантування у вищих військових навчальних закладах. // Вісник Національного авіаційного університету, К., 2017. - №1(10). - С.65-70.

17. Кремень В.Г. Освіта і наука України: шляхи модернізації (Факти, роздуми, перспективи). - К.: Грамота, 2003. - 216 с.

18. Максименко С. Д. Механізми трансформації структурних компонентів діяльності у професійному розвитку особистості в сучасних умовах / С. Д. Максименко // Актуальні проблеми становлення особистості професіонала в ризиконебезпечних професіях: матеріали міжрегіон. наук. Семінару (Київ, 25 березня 2010 р.) / Мін-во оборони України, Національний університет оборони України. - К.: НУОУ, 2010. - С. 12-14.

19. Международный стандарт ISO:9000. Системы менеджмента качества - Основные положения и словарь [Электронный pecypc]. - Режим доступа: http://www.pqmonline.com/assets/files/pubs/translations/std/iso-9000-2015-(rus).pdf.

20. Модернізація системи військової освіти України та формування загального обрису офіцера майбутнього: реалії і перспективи / О. Васильєв, О. Заболотний, А. Зельницький та ін. // Військова освіта: збірник наукових праць НУОУ імені Івана Черняховського. - 2019. № 1(39). - С. 70-81.

21. Моніторинг якості підготовки військових фахівців у вищих військових навчальних закладах та військових навчальних підрозділах вищих навчальних закладів Збройних Сил України: наук. -метод посіб. /А.М. Зельницький, О.А. Заболотний, Ю.І. Приходько та ін.; за заг. ред. І.В. Толока.- Харків: ХНУПС, 2017. - 244 с.

22. Мул С. А. Психологія готовності офіцера-прикордонника до професійної діяльності: дис. докт. психол. наук : 19.00.01. Київ, 2016. - 539 с.

23. Осьодло В.І. Психологія професійного становлення офіцера: [монографія]. Київ : ПП «Золоті ворота», 2012.- 463 с.

24. Рамський Ю. С. Формування інформаційної культури особи - пріоритетне завдання сучасної освітньої діяльності // Науковий часопис НПУ імені М.П. Драгоманова. Серія № 2. Комп'ютерно-орієнтовані системи навчання: Зб. наукових праць. - К.: НПУ імені М.П. Драгоманова, 2004. - № 1(8). - С.19-42.

25. Сучасний словник іншомовних слів / Уклад. О. І. Скопенко, Т. В. Цимбалюк. - К.: Довіра, 2006. - 789 с. (Словники України).

26. Торбіна Т. Професійно значущі якості особистості сучасного фахівця / Т. Торбіна // Проблеми підготовки сучасного вчителя. - 2012. - № 5 (Ч. 1). - С. 76-81.

27. Тришина С. В., Хуторской А.В. Информационная компетентность специалиста в системе дополнительного профессионального образования // Интернет-журнал «Эйдос». 2004, 22 июня // URL: http://www.eidos.ru/journal/2004/0622-09.htm

28. Указ Президента України №392/2020 «Про рішення Ради національної безпеки і оборони України від 14 вересня 2020 року «Про Стратегію національної безпеки України»

29. Шадриков В. Д. Новая модель специалиста: инновационная подготовка и компетентностный подход / В. Д. Шадриков / Высшее образование сегодня. - 2004. - № 8. C. 26-31.

30. Ягупов В. В. Компетентнісний підхід до підготовки фахівців у системі вищої освіти / В.В. Ягупов, В.І. Свистун // Наукові записки. Серія: Педагогічні, психологічні науки та соціальна робота. - 2007. - Том 71. - С. 3-8. 


\section{REFERENCES}

1. Andrushchenko V.P. (2001)Teoretyko-metodolohichni zasady modernizatsiyi vyshchoyi osvity $\mathrm{v}$ Ukrayiny na rubezhi stolitty (za materialamy dopovidi, vyholoshenoyi na zasidanni zahalnykh zboriv APN Ukrayiny 23 lystopada 2000 r.) // Vyshcha osvita Ukrayiny. - № 2. - S. 513 (in Ukrainian).

2. Antonchenko M.A. (2004) Informatsiyna kultura yak skladova zahalnolyudskoyi kultury // Naukovyy chasopys NPU imeni M.P. Drahomanova. Seriya № 2. Kompyuterno-oriyentovani systemy navchannya: Zb. Naukovykh prats. - K.: NPU imeni M.P. Drahomanova. - № 1(8). s.161-166 (in Ukrainian).

3. Astakhova L.V. (2013) Ponyatye ynformatsyonnoy kompetentsyy spetsyalysta: kohnytyvnyy podkhod // Vestnyk YUUr-HU. Seryya: Obrazovanye. Pedahohycheskye nauky. №4. - S. 10-16 (in Russian).

4. Balovsyak M. (2004) Informatsiyna kompetentnist fakhivtsya // Pedahohika i psykholohiya profesiynoyi osvity. - № 5. - s. 21-28 (in Ukrainian).

5. Velykyy tlumachnyy slovnyk suchasnoyi ukrayinskoyi movy (2001) / Uklad. i holov. red. V.T. Busel. - K.-Irpin: VTF "Perun". - 1440 s (in Ukrainian).

6. Vitchenko A.O., Osodlo V.I., Salkutsan S.M. (2016) Tekhnolohiyi navchannya u vyshchiy viyskoviy shkoli: teoriya i praktyka: navch.-metod. posib. / za zah. red. profesora V.M. Telelyma. K. : NUOU im. Ivana Chernyakhovskoho. - 272 s (in Ukrainian).

7. Hershunskyy B.S. (1998) Fylosofyya obrazovanyya. - M.: «Flynta». - 492 s (in Russian).

8. Honcharenko S.U. (1997) Ukrayinskyy pedahohichnyy slovnyk. - K.: Lybid. - 376 s (in Ukrainian).

9. Yevsyukov O.P. (2007) Psykholohichne prohnozuvannya profesiynoyi nadiynosti fakhivtsiv avariyno-ryatuvalnykh pidrozdiliv MNS Ukrayiny : dys. ...kandydata ped. nauk : 19.00.09/ Yevsyukov Oleksandr Petrovych. - Kharkiv. - S. 90 (in Ukrainian).

10. Zaytseva O.B. (2004) Ynformatsyonnaya kompetentnost uchytelya obrazovatelnoy oblasty «Tekhnolohyya» / O.B.Zaytseva // Pedahohyka. - № 4. - S.17-23 (in Russian).

11. Pro osvitu : Zakon Ukrayiny vid 05.09.2017 r. №2145-VIII. // Vidomosti Verkhovnoyi Rady, 2017. - № 38-39. - St. 380 (in Ukrainian).

12. Pro vyshchu osvitu : Zakon Ukrayiny vid 01.07.2014 r. № 1556-VII. (Data onovlennya: 28.09.2017.) URL: http://zakon4.rada.gov.ua/laws/show/1556-18/page2 (data zvernennya: 15.11.2017) (in Ukrainian).

13. Zelnytskyy A.M. (2009) Kompetentnisna model vypusknyka VVNZ - skladova systemy pidhotovky viyskovykh fakhivtsiv / Zelnytskyy A.M., Udovenko P.I., Servetnyk R.M. // Visnyk Natsionalnoyi akademiyi oborony Ukrayiny. - № 3 (11). - S. 21-26 (in Ukrainian).

14. Zelnytskyy A. M. (2011) Vidhuk z viysk na vypusknyka VVNZ, VNP VNZ u systemi upravlinnya yakistyu pidhotovky viyskovykh fakhivtsiv / A. M. Zel'nyts'kyy // Visnyk Natsionalnoho universytetu oborony Ukrayiny. - Vyp. 1. - S. 14-25 (in Ukrainian).

15. Zelnytskyy A.M. (2015) Problema yakosti pidhotovky ofitseriv taktychnoyi lanky upravlinnya v konteksti provedennya ATO / A.M. Zelnytskyy, YU.I. Prykhodko, O.O. Mityahin // Zbirnyk nauk. prats «Viyskova osvita» Natsionalnoho universystetu oborony Ukrany. - № 1(31). S. 93-102 (in Ukrainian).

16. Zelnytskyy A.M. (2017) Yakist viyskovoyi osvity: yiyi zabezpechennya ta harantuvannya u vyshchykh viyskovykh navchalnykh zakladakh. Visnyk Natsionalnoho aviatsiynoho universytetu, - K. - №1(10). - S.65-70 (in Ukrainian).

17. Kremen V.H. (2003) Osvita i nauka Ukrayiny: shlyakhy modernizatsiyi (Fakty, rozdumy, perspektyvy). - K.: Hramota, 2003. - 216 s (in Ukrainian).

18. Maksymenko S. D. (2010) Mekhanizmy transformatsiyi strukturnykh komponentiv diyalnosti u profesiynomu rozvytku osobystosti v suchasnykh umovakh / S. D. Maksymenko // Aktualni problemy stanovlennya osobystosti profesionala $\mathrm{v}$ ryzykonebezpechnykh profesiyakh: materialy mizhrehion. nauk. Seminaru (Kyyiv, 25 bereznya 2010 r.) / Min-vo oborony Ukrayiny, Natsionalnyy universytet oborony Ukrayiny. - K.: NUOU. - S. 12-14 (in Ukrainian). 
19. Mezhdunarodnyy standart ISO:9000. Systemy menedzhmenta kachestva - Osnovnye polozhenyya y slovar [Élektronnyy resurs]. - Rezhym dostupa: http://www.pqmonline.com/assets/files/pubs/translations/std/iso-9000-2015-(rus).pdf. (in Russian).

20. Modernizatsiya systemy viyskovoyi osvity Ukrayiny ta formuvannya zahalnoho obrysu ofitsera maybutnoho: realiyi i perspektyvy (2019) / O. Vasylyev, O. Zabolotnyy, A. Zelnytskyy ta in. // Viyskova osvita : zbirnyk naukovykh prats NUOU imeni Ivana Chernyakhovskoho. - № 1 (39). - S. 70-81 (in Ukrainian).

21. Monitorynh yakosti pidhotovky viyskovykh fakhivtsiv u vyshchykh viyskovykh navchalnykh zakladakh ta viyskovykh navchalnykh pidrozdilakh vyshchykh navchalnykh zakladiv Zbroynykh Syl Ukrayiny: nauk.-metod posib. (2017) /A.M. Zelnytskyy, O.A. Zabolotnyy, YU.I. Prykhod'ko ta in..; za zah. red. I.V. Toloka.- Harkiv: KHNUPS. - s. 98 (in Ukrainian).

22. Mul S.A. (2016) Psykholohiya hotovnosti ofitsera-prykordonnyka do profesiynoyi diyalnosti : dys. dokt. psykhol. nauk : 19.00.01. Kyyiv. - 539 s (in Ukrainian).

23. Osodlo V.I. (2012) Psykholohiya profesiynoho stanovlennya ofitsera : [monohrafiya]. Kyyiv : PP «Zoloti vorota». - 463 s (in Ukrainian).

24. Ramskyy Y.S. (2004) Formuvannya informatsiynoyi kultury osoby - priorytetne zavdannya suchasnoyi osvitnoyi diyalnosti // Naukovyy chasopys NPU imeni M.P. Drahomanova. Seriya № 2. Kompyuterno-oriyentovani systemy navchannya: Zb. Naukovykh prats. - K.: NPU imeni M.P. Drahomanova. - № 1(8). - s.19-42 (in Ukrainian).

25. Suchasnyy slovnyk inshomovnykh sliv (2006) / Uklad. O. I. Skopenko, T. V.Tsymbalyuk. - K.: Dovira. - 789 s. - (Slovanyky Ukrayiny) (in Ukrainian).

26. Torbina T. (2012) Profesiyno znachushchi yakosti osobystosti suchasnoho fakhivtsya / T. Torbina // Problemy pidhotovky suchasnoho vchytelya. - № 5 (CH. 1). - S. 76-81 (in Ukrainian).

27. Tryshyna S.V., Khutorskoy A.V. (2004) Ynformatsyonnaya kompetentnost spetsyalysta v systeme dopolnytelnoho professyonalnoho obrazovanyya // Ynternet-zhurnal «Éydos». 22 yyunya // URL: http://www.eidos.ru/journal/2004/0622-09.htm (in Russian).

28. Ukaz Prezydenta Ukrayiny № 392/2020 «Pro rishennya Rady natsionalnoyi bezpeky i oborony Ukrayiny vid 14 veresnya 2020 roku «Pro Stratehiyu natsionalnoyi bezpeky Ukrayiny» (in Ukrainian).

29. Shadrikov V.D. (2004) Novaya model spetsyalysta: ynnovatsyonnaya podhotovka y kompetentnostnyy podkhod / V. D. Shadrykov // Vysshee obrazovanye sehodnya. - № 8. - S. 2631 (in Russian).

30. Yahupov V.V. (2007) Kompetentnisnyy pidkhid do pidhotovky fakhivtsiv u systemi vyshchoyi osvity / V.V. Yahupov, V.I. Svystun // Naukovi zapysky. Seriya: Pedahohichni, psykholohichni nauky ta sotsialna robota. - Tom 71. - S. 3-8 (in Ukrainian).

\title{
PЕЗЮМЕ
}

Андрей Зельницкий, кандидат педагогических наук, профессор

Олег Заболотный, кандидат военных наук, доцент

Александр Васильев,

Надежда Шабатина

Национальный університет обороны Украины имени Ивана Черняховского

\author{
ИНФОРМАЦИОНО-КОММУНИКАТИВНАЯ КОМПЕТЕНТНОСТЬ \\ ВЫПУСКНИКА ВЫСШЕГО ВОЕННО-УЧЕБНОГО ЗАВЕДЕНИЯ: \\ СТРУКТУРА, СОДЕРЖАНИЕ, ИЗМЕРЕНИЕ, ОЦЕНИВАНИЕ
}


B статье анализируются научные подходь $\kappa$ определению общего понятия "информационно-коммуникативная компетентность" (далее - ИКК) и ее основных компонентов. Рассматриваются структура и содержание ИКК и процедуры их адаптации $\kappa$ особенностям организащии образовательного процесса в высших военных учебных заведениях и военных учебных подразделениях высших учебных заведений. Исследуются актуальные проблемы по внедрению в педагогическую практику военных вузов разработанного инструментария по измерению и оценке уровня сформированности ИКК $у$ слушателей (курсантов) вуза как элемента обратной связи в системе управления качеством выстего военного образования. Исследование гармонизированы $c$ положениями Национальной рамки квалификаџий, Европейской кредитно-трансферной системы, Уставов Вооруженных Сил Украины, стандартов образования и профессиональных стандартов подготовки военных специалистов, другими нормативно-правовыми актами.

Ключевые слова: профессиональная компетентность будущих офицеров; информачионно-коммуникачионная компетентность; профессионально важные качества; показатели измерения; критерии оценки; обратная связь.

\title{
SUMMARY
}

\author{
Andrii Zelnytskyi, \\ $\mathrm{PhD}$ (Pedagogical Sciences), Professor \\ Oleh Zabolotnyi, \\ $\mathrm{PhD}$ (Military Sciences), Associate Professor \\ Oleksandr Vasyliev, \\ Nadiya Shabatina \\ National Defence University of Ukraine \\ named after Ivan Cherniakhovskyi
}

\section{INFORMATION AND COMMUNICATIVE COMPETENCE OF A GRADUATE OF A HIGHER MILITARY EDUCATIONAL INSTITUTION: STRUCTURE, CONTENT, MEASUREMENT, EVALUATION}

Introduction. The article analyzes scientific approaches to the definition of the concept of "information and communicative competence and its main components. The structure and content of the ICC and the procedures for their adaptation to the peculiarities of the organization of the educational process in higher military educational institutions and military educational units of higher educational institutions are considered. The current problems of introduction into pedagogical practice of military universities of the developed tools for measuring and evaluating the level of formation of cadets' ICC as an element of feedback in the quality management system of higher military education are investigated. The study was harmonized with the provisions of the National Qualifications Framework, the European Credit Transfer System, the Charters of the Armed Forces of Ukraine, educational standards and professional training standards for military specialists, and other regulatory legal acts.

Purpose. The purpose of the article is to substantiate conceptual approaches to determining the structure and content of information and communication competence of a military graduate, to develop tools for measuring the level of its formation and to test the developed tools (in selfassessment mode) with the participation of cadets.

Research methods. The study was conducted using the following theoretical methods: systems analysis and synthesis, induction and deduction, comparison, classification, generalization and systematization; idealization and abstraction.

Results. The article proposed the analysis of the information and communicative competence definition and the competence-based model was proposed. 
Originality. The ICC and the procedures for their adaptation to the peculiarities of the organization of the educational process in higher military educational institutions and military educational units of higher educational institutions are considered in the article for the first time.

Conclusion. The article analyzes the content of the concept of "information and communicative competence", which is adapted to the peculiarities of the organization of the educational process in higher military educational institutions and military educational units of higher education institutions. The ICC competence-based model has been developed, the structural elements of which are organically interconnected, such as professionally important qualities of future officers in terms of their ability and willingness to navigate information flows, find, perceive, analyze, store and use information in professional activities.

Key words: professional competence of future officers; information and communication competence; professionally important qualities; measurement indicators; criteria for evaluation; feedback. 